\title{
Growth and Oil Yield of Sesame as Influenced by Sulphur and
} Nitrogen

\author{
Ahmad J1*, Ahmad F1, Iqbal S1, Shah SMA1, Ali M11, Abbas MW1, Nawaz \\ $\mathrm{H}^{1}$, Mehmood Z1 $\mathrm{Z}^{1}$ Ali B ${ }^{2}$ and Ali $\mathrm{S}^{3}$ \\ ${ }^{1}$ Department of Agronomy, Faculty of Crop Production Sciences, Pakistan \\ 2Department of Soil and Environmental Science, Pakistan
}

Research Article

Volume 3 Issue 7

Received Date: August 20, 2018

Published Date: August 31, 2018

${ }^{3}$ Department of Plant Protection Science, The University of Agriculture, Peshawar-Pakistan

*Corresponding author: Junaid Ahmad, Department of Agronomy, Faculty of Crop Production Sciences, Pakistan, Email: Junaid.agri@aup.edu.pk

\begin{abstract}
According to cropping system of Pakistan, sesame crop response to nutrient management (nitrogen and sulfur) need to be optimized for successful farming and good cost of production. A field trial was conducted at Agronomy Research Farm, The University of Agriculture, Peshawar during summer 2017 with the objective to find out the effect of different nitrogen and sulfur levels, $\left(0,25,50,75\right.$, and $\left.100 \mathrm{~kg} \mathrm{ha}^{-1}\right),\left(0,10,20,30\right.$, and $\left.40 \mathrm{~kg} \mathrm{ha}^{-1}\right)$ respectively on oil and grain yield of black sesame seeds. The experiment was conducted in randomized complete block (RCB) design with three replications. Urea and Ammonium sulfate was applied as source for nitrogen and sulfur respectively. The results showed that days to emergence were not significantly affected by nitrogen and sulfur application. The application of nitrogen at the rate of $100 \mathrm{~kg} \mathrm{ha}^{-1}$ produced maximum number of branches plant ${ }^{-1}(13)$, number of capsules plant ${ }^{-1}(82)$, seed yield (899 kg ha-1), biological yield (4084 $\mathrm{kg} \mathrm{ha}^{-1}$ ), oil content (46.21\%) and oil yield (423 kg ha-1) with taller plants (179.56 $\mathrm{cm})$. Sulfur applied at the rate of $40 \mathrm{~kg} \mathrm{ha}^{-1}$ maintained higher plant height $(183.14 \mathrm{~cm})$, number of branches plant-1 (13), number of capsules plant-1 (85), seed yield (876 kg ha-1), biological yield (4069 kg ha-1), oil content (48.28\%) and oil yield (419 $\mathrm{kg} \mathrm{ha}^{-1}$ ). It is concluded that application of nitrogen at the rate of $100 \mathrm{~kg} \mathrm{ha}^{-1}$ and sulfur at the rate of $40 \mathrm{~kg} \mathrm{ha}^{-1}$ produced higher oil and seed yield of sesame and thus recommended for general cultivation.
\end{abstract}

Keywords: Sesame; Nitrogen; Sulfur; Agronomy; Oil Content; Oil Yield; Capsules; Branches

\section{Introduction}

Sesame (Sesamum indicum L.) is one of the most important oil seed crops belongs to Pedaliaceae family and extensively grown in different parts of the world and it ranks fourth among oil seed crops in the world. Sesame is considered as a drought tolerant crop [1]. In Pakistan, sesame was cultivated on an area of 90.7 ha with an 


\section{Open Access Journal of Agricultural Research}

annual production of 41 tones and an average yield of 452 $\mathrm{kg} \mathrm{ha}^{-1}$ in Pakistan whereas in Khyber Pakhtunkhwa its average yield was $500 \mathrm{~kg} \mathrm{ha}^{-1}$ [2]. Sesame is drought resistant crop, which can be easily grown under rainfed conditions and it has been grown all over the world for thousands of years [3]. Sesame is a versatile crop with high quality edible oil having diversified usage. Sesame contains $4655 \%$ oil, $20-25 \%$ protein and also contains vitamins, amino acids and polyunsaturated fatty acids. Sesame can play an important role to fulfill the local demand of edible oil. Many unsaturated fatty acids are present in sesame seeds such as linoleic and oleic acids that are mainly responsible for oil quality [4].

Oilseed crops require more sulphur for their growth compared with cereals, as $S$ promotes pod formation, whereas its deficiency can abort the pods. Sulphur (S) is considered as the fourth main plant nutrient after nitrogen, phosphorus and potassium, and its low availability in various soils causes the innate sulphur deficiency. High yield and quality of oilseed crops are possible only when crops have access to the optimum amount of sulphur [5]. Sulphur plays a key role in the plant metabolism, indispensable for the synthesis of essential oils, chlorophyll formation, required for development of cells and it also increases cold resistance and drought hardiness of crops especially for oilseed crops [6]. Sulphur application increases oil and protein contents in seeds. It also increases the availability of other nutrients such as phosphorus, potassium, zinc and suppresses the uptake of sodium and chlorine which are toxic to plant growth and development. In general, the sufficient amount of sulphur application significantly increases crop growth and improves the quality of sesame by increasing protein and oil contents [7].

Nitrogen is most important nutrient for enlargement of leaf and expansion of roots. Due to these reasons, nitrogen increased crop yield and quality [8]. Among the various factors of crop production proper sowing dates, nitrogen levels, sulfur levels and improved sesame cultivars play a key role in enhancing its production. Keeping in view the above limitations this research was conducted to check out the impact of nitrogen and sulfur levels on the yield and yield components of sesame at the agro-climatic condition of Northwestern Pakistan.

\section{Materials and Methods}

Growth and oil yield of sesame as influenced by nitrogen and sulfur was evaluated at Agronomy Research Farm, The University of Agriculture, Peshawar during summer 2017. The experiment was laid out in randomized complete block design and replicated thrice. Four levels of nitrogen $\left(20,40,60\right.$ and $\left.80 \mathrm{~kg} \mathrm{ha}^{-1}\right)$, and four levels of sulfur $\left(10,20,30\right.$, and $\left.40 \mathrm{~kg} \mathrm{ha}^{-1}\right)$ were used in the experiment. One control plot with no nitrogen and sulfur was maintained in each replication. Urea and Ammonium sulfate was used as source of nitrogen and sulfur respectively. Plot size of $3 \mathrm{~m} \times 3.6 \mathrm{~m}$, having 6 rows with row to row distance of $60 \mathrm{~cm}$ was maintained. Local black seed was sown at the rate of $4 \mathrm{~kg} \mathrm{ha}^{-1}$ on $25^{\text {th }}$ June 2017 and crop was harvested on $13^{\text {th }}$ October 2016. All agronomic practices were carried out uniformly throughout the growing season.

\section{Results and Discussion}

\section{Days to Emergence}

Days to emergence and emergence $\mathrm{m}^{-2}$ of sesame was not significantly affected by nitrogen and sulfur application. At earlier stages seed uses its own reserve food till emergence and thus application of nitrogen and sulfur had no significant effect on days to emergence and emergence $\mathrm{m}^{-2}$. These results are in line with who reported that nitrogen and sulfur had no significant impact on days to emergence and emergence $\mathrm{m}^{-2}$ of sesame [9]. These finding are also supported by who stated that seed utilizes its endospermic reserved food (carbohydrates, minerals and protein) which fulfill the requirements for seed germination [10].

\section{Branches Plant-1}

Number of branches plant ${ }^{-1}$ increased with increasing nitrogen levels upto $100 \mathrm{~kg} \mathrm{~N}^{-1}$ produced maximum number of branches plant ${ }^{-1}$ as compared to control plots. The reason might be the availability of more nutrients due to higher level of $\mathrm{N}$ application enabled crop to uptake more nutrients and grow vigorously and thus resulted in improved crop growth and more branches plant ${ }^{-1}$. These results are in line with [11]. Who observed maximum number of branches plant ${ }^{-1}$ were significantly higher in plots fertilized with higher rates of nitrogen $100 \mathrm{~kg} \mathrm{ha}^{-1} \mathrm{~N}$. Branches plant ${ }^{-1}$ also increased with increasing sulfur levels and higher branches plant ${ }^{-1}$ were recorded in plots where $40 \mathrm{~kg} \mathrm{ha}^{-1}$ sulfur was applied. Higher branches plant $^{-1}$ with increased sulfur application levels might be due the fact that higher doses of sulfur enhanced the metabolic and meristematic activities of crop resulting in optimum growth, plant height and branches plant ${ }^{-1}$ of sesame. Similar results are also reported by who observed taller plants with higher primary and secondary branches plant ${ }^{-1}$ of sesame through higher levels of sulfur application [11]. 


\section{Open Access Journal of Agricultural Research}

\section{Capsules Plant ${ }^{-1}$}

Number of capsules plant ${ }^{-1}$ of sesame was significantly influenced by the application of various nitrogen and sulfur levels. Number of capsules plant ${ }^{-1}$ considerably increased with increasing $\mathrm{N}$ fertilization upto $100 \mathrm{~kg}$ ha${ }^{1}$ and further increase in nitrogen levels showed no significant increase in capsules plant ${ }^{-1}$ of sesame. Similar results were reported by who concluded that increase in capsules plant ${ }^{-1}$ might be due to active nutrients uptake and vigorous vegetative growth of crop due to higher $\mathrm{N}$ application levels [12]. Regarding sulfur levels, capsules plant $^{-1}$ linearly increased with increasing sulfur levels and higher capsules plants ${ }^{-1}$ were observed in plots fertilized with $40 \mathrm{~kg} \mathrm{ha}^{-1}$ sulfur as compared to control plots. Similar results are reported by who reported significant increase in number of capsules plant ${ }^{-1}$ of sesame with increase in sulfur levels [13].

\section{Seed Yield (kg ha-1)}

Seed yield is the ultimate goal of any crop under study. Average mean data showed that seed yield was significantly influenced by nitrogen and sulfur rates. Maximum seed yield was obtained by nitrogen applied at the rate of $100 \mathrm{~kg} \mathrm{ha}^{-1}$ while minimum seed yield were obtained from control plot. This might be due to positive impact on growth and yield attributes including plant height, capsules plant ${ }^{-1}$ and thousand grain weight which ultimately increased seed yield. Similar results are reported by that with the application of nitrogen the yield attributes like capsules plant ${ }^{-1}$, number of seeds capsule ${ }^{-1}$ and thousand seed weight increased which might have increased the grain yield [14]. Sulfur produce maximum seed yield at $40 \mathrm{~kg} \mathrm{ha}^{-1}$ as compared to control. The high yield may be due to stimulatory effect of sulfur on protein synthesis that further enhanced photosynthesis and yield contributing components which resulted in maximum seed yield [15].

\section{Biological Yield (kg ha-1)}

Our results showed that maximum biological yield was produced by the application of nitrogen at $100 \mathrm{~kg} \mathrm{ha}^{-1}$ and sulfur $40 \mathrm{~kg} \mathrm{ha}^{-1}$. These significant results might be associated with maximum plant height, number of branches and number of capsule plant ${ }^{-1}$ which enhanced total biomass of the plant. Significant effect of nitrogen fertilizer on biological yield could have resulted from the fact that nitrogen is the principal constituent of proteins, enzymes, hormones and chlorophyll which contribute to improved leaf area index and increased biological yield. Regarding sulfur application observed that biological yield was significantly increased with sulfur rates because it stimulates chloroplast protein synthesis resulted in better photosynthetic efficiency and finally increased the biological yield [16]. Sulfur enhance biological yield which might be due to the supplementary synthesis of amino acid and chlorophyll content in growing regions, as a result increased in cell division further enhance leaf area index, height and dry matter yield [7].

\section{Oil Content}

Oil content varied significantly with different nitrogen and sulfur levels. Oil content increased with increase in nitrogen rates up to $100 \mathrm{~kg} \mathrm{ha}^{-1}$ but showed significant decrease with increased in nitrogen rates above $100 \mathrm{~kg}$ ha $^{-1}$. Both protein and oil has inverse relation in terms of their synthesis with in plant body. As nitrogen increased, it favored protein and decreased oil content. These results are supported by they reported that oil content of sesame increased up to $100 \mathrm{~kg} \mathrm{~N} \mathrm{ha}^{-1}$ application while further increased in nitrogen, oil content were decreased [17]. Higher oil content was recorded when $40 \mathrm{~kg} \mathrm{~S}^{-1} \mathrm{~h}^{-1}$ was applied as compared to control plot. Sulfur helps in the activation of enzymes which help in biochemical reaction in plant and increase the oil content in sesame crop [18].

\section{Oil Yield}

Higher oil yield was obtained from plants fertilized with nitrogen at the rate of $100 \mathrm{~kg} \mathrm{ha}^{-1}$ while less oil yield was obtained from control plots. This was might be due to the fact that oil yield is more affected by seed yield than seed oil content. Our results are supported by who stated that increasing nitrogen application will raise oil yield in addition to seed yield [19]. Sulfur fertilization significantly increased the oil yield and the maximum oil yield was recorded in plots treated with $40 \mathrm{~kg} \mathrm{~S} \mathrm{ha}^{-1}$.Our findings are in related with the observation of who reported higher oil content and oil yield of sesame with sulfur fertilization [7].

\section{References}

1. Alpaslan M, Boydak E, Hayat M, Grereck S, Simsek M (2001) Effect of row spacing and irrigation on seed composition of Turkish sesame. J of the American oil chemist's Society 78(9).

2. MINFAL (2015) Ministry for Food, Agriculture and Livestock. Govt of Pakistan, economic wing, Islamabad.

3. Mamatha K, Sagar V, Narayana PL, Padmaja G 0 Sesame (Sesamumindicum L.) as influenced by application of Sulphur with farmyard manure. 


\section{Open Access Journal of Agricultural Research}

International Journal of Current Research 7(12): 24021-24024.

4. Uzun B, Arslan C,, FURAT Ş (2008) Variation in fatty acid compositions, oil content and oil yield in a germplasm collection of sesame (Sesamumindicum L.). J Am Oil Chem Soc 85(12): 1135-1142.

5. Scherer HW (2001) Sulphur in crop productionInvited paper. Eur J Agron 14(2): 81-111.

6. Patel JR, Shelke VB (1995) Effect of farmyard manure, phosphorus and sulphur on growth, yield and quality of Indian mustard. Indian J Agron 43: 713-717.

7. Raja A, Hattab KO, Gurusamy L, Suganya S (2007) Suphur levels on nutrients uptake and yield of sesame varieties and nutrients availability. Int J Soil Sci 2 (4): 278-285.

8. Khalil IA, Jan A (2002) Cropping technology. National book Foundation, Islamabad.

9. Mahdi AAR (2008) Response of sesame to nitrogen and phosphorus fertilization in Northern Sudan. Journal of Applied Biosciences 8(2): 304-308.

10. Shilpi S, Islam MN, Sutradhar GNC, Husna A, Akter F (2012) Effect of nitrogen and sulfur on the growth and yield of sesame. Int J Biores Stress Manag 3(2): 177-182.

11. Khan N, Khalil SK, Amanullah A, Ali Z, Ullah, Ali M (2016) Effect of nitrogen and sulfur on yield and yield components of sesame (Sesamumindicum L.) in calcareous soil. Pure and Appl Bio 5(3): 471-475.

12. Tahir M, Ibrahim MA, Tahir S, Ayub A, Tanveer A, et al. (2015) Effect of sulfur levels on two sesame
(Sesamum indicum L.) varieties under climatic conditions of Pakistan. Int J Plant and Soil Sci 3(3): 281-288.

13. Heidari M, Galavi M, Hassani M (2011) Effect of sulfur and iron fertilizers on yield, yield components and nutrient uptake in sesame (Sesamum indicum L.) under water stress. Afric J Biotec 10(44): 8695-8702.

14. Ahmed A, Akhtar M, Hussain A, Ullah E, Musaddique M (2001) Genotypic response of sesame to nitrogen and phosphorus application. Pak J Agric Sci 38(1-2): 12-15.

15. Mondal MMA, Badruddin M, Malek M, Hossainand M, Puteh A (2012) Optimization of sulphur requirement to sesame (Sesamum indicum L.) genotypes using tracer techniques. J Bot 41(1): 7-13.

16. Shah MA, Manaf A, Hussain M, Farooq S, Zafar-Ul-Hye M (2013) Sulphur fertilization improves the sesame productivity and economic returns under rainfed conditions. Int J Agric Biol 15(6): 1301-1306.

17. Gawand PB, Deshpande AN, Tambe SI, Reddy BN, Pharande AL (2005) Effect of nutrient and moisture conservation practices on growth, yield and economics of rabi safflower under rain fed low $\mathrm{P}$ Vertisols. Sesame and Safflower Newsletter 20: 75-77.

18. Maragatham S, Geetha SA, Swamy MG (2006) Response of sesame to Sulfur fertilization. J Eco Biol 18(4): 391-394.

19. Mujaya IM, Yerokan OA (2003) Response of sesame (Sesamum indicum L.) to plant population and nitrogen fertilizer in north-central Zimbabwe. Sesame and Safflower Newsletter 18: 64-69. 